MóRÉ TÜNDE

\title{
Elmélkedés, hitvita, káté Károlyi Péter Az halalrol, fel tamadasrol es az örök eletröl címü munkájában*
}

Bán Imre 1971-es kismonográfiájában ${ }^{1}$ mutatta be Károlyi Péter ${ }^{2}$ poétikai kézikönyvét. Tanulmánya a magyar retorikatörténeti kutatások egyik kezdőpontja. Károlyi Péter életmüve azonban igen kevés figyelmet kapott az azóta eltelt évtizedekben. Korábban Nagy Kálozi Balázs tekintette át Károlyi munkásságát, ${ }^{3}$ müveit leginkább poétikatörténeti, ${ }^{4}$ könyvtörténeti ${ }^{5}$ szempontból vizsgálták. Az Az halalrol, fel tamadasrol es az örök eletröl címủ munkáját vitairat és elmélkedés címkével látták el. A szakirodalom inkább a mű hitvitázó jellege iránt érdeklődött; ugyan többen is említik az írás vigasztaló szándékát, ebből a szempontból mégsem vizsgálták részletesebben. Tanulmányomban arra teszek kísérletet, hogy az elmélkedés, a hitvita valamint a káté müfaji jellemzőit vizsgáljam Károlyi Péter 1575-ben megjelent írásában.

1.

Kanyaró Ferenc a múlt század fordulóján két írásában is tárgyalta Károlyinak ezt a munkáját, amelyet a hitviták kontextusában vizsgált. ${ }^{6}$ Melius Juhász Péter tanítványa-

\footnotetext{
“A kutatás az Európai Unió és Magyarország támogatásával, az Európai Szociális Alap társfinanszírozásával a TÁMOP 4.2.4 A/2-11-1-2012-0001 azonosító számú „Nemzeti Kiválóság Program - Hazai hallgatói, illetve kutatói személyi támogatást biztosító rendszer kidolgozása és müködtetése konvergencia program” címü kiemelt projekt keretei között valósult meg.

${ }^{1}$ BÁN Imre, Irodalomelméleti kézikönyvek Magyarországon a XVI-XVIII. században, Bp., Akadémiai, 1971, 9-13.

${ }^{2}$ Károlyi Péter 1563. december 16-án iratkozott be a wittenbergi egyetemre, és 1564 folyamán is ott tartózkodott. (SzöGI László, Magyarországi diákok németországi egyetemeken és akadémiákon, 1526-1700, Bp., ELTE Levéltára, 2011, 272.) Hazatérését követően elöször Kolozsvárott folytatott hitvitát Dávid Ferenccel (1566), majd Nagyváradon működött rektorként. Nem sokkal később ismét lelkészi szolgálatot vállalt (1568). Ezután vett részt a gyulafehérvári második és a nagyváradi harmadik hitvitán. Melius Juhász Péter halálát követően, 1573-ban püspökké választották, ezt a tisztséget haláláig betöltötte.

${ }^{3}$ Nagy Kálozi Balázs, Károlyi Péter = A II. Helvét hitvallás Magyarországon és Méliusz életmüve, szerk. BARTHA Tibor, Bp., A Magyarországi Református Egyház Zsinati Irodájának Sajtóosztálya, 1967, 473-515. ${ }^{4}$ BARTók István, A tanár és a költö: Károlyi Péter és Gyöngyösi István = Szolgálatomat ajánlom a 60 éves Jankovics Józsefnek, szerk. Császtvay Tünde, Nyerges Judit, Bp., Balassi, MTA Irodalomtudományi Intézet, 2009, 30-34.

${ }^{5}$ BÁNFi Szilvia, Ujabb adalékok az 1570-es esztendő református és unitárius sajtópolémiáihoz = Translatio Librorum: Tanulmányok az Oroszországból Sárospatakra visszaszolgáltatott könyvek kapcsán, szerk. Jekatyerina Jurjevna Genyijevna, Kiss Ilona, MonoK István, Bp., OSzK, 2007, 41-75; Uő, A csíksomlyói ferences gyüjteményben lappangó ismeretlen, 16. századi debreceni nyomtatvány-töredék, MKsz, 2000/4, 417-442.

${ }^{6}$ Kanyaró Ferenc, Protestáns vitairatok Mélius idejéből, MKsz, 1896/4, 321-338; Uö, Melius ismeretlen és elveszett müvei, MKsz, 1906/4, 289-320.
} 
ként tekintett Károlyira, így értelmezte tevékenységét, és ezzel meghatározta a későbbi Károlyi-elemzések alapvetését. Ennél többet nem is igen árult el róla, hiszen „élete sokkal ismeretesebb, hogysem a mi fogyatékos ismertetésünkre szorulna."7 Kanyaró szerint Károlyi írása juttatta nyugvópontra a lélek feltámadásáról szóló vitában a felekezetek közötti ellentéteket. Kanyaró az anabaptistákhoz köti a vita elindulását, akik ellen Kálvin Psychopannychia címü müve is szólt. A kérdés magyarországi tárgyalását $A$ szentek aluvásáról címet viselő, azóta elveszett Dévai Bíró Mátyás-irat nyitotta meg. A Dévai nyomán született válasziratok sem maradtak fenn: Sztárai Mihály az 1560-as években írhatott erről a kérdésről, amelyre Melius válaszolt a Halál könyve című, valószínűleg 1563-ban megjelent művével, ezt pedig Sztárai válasza követhette. Az ellentét oka a lutheránus-kálvinista felfogás különbségében rejlik, mivel Kálvin elutasította, Luther pedig változtatásokkal elfogadta a mortalizmus tanát. ${ }^{8}$ Ehhez kapcsolódva jelzi lábjegyzetben Kanyaró, hogy eredetileg Tót Miklós és Sommer János Kolozsvárott megjelent müve ellen írta volna Károlyi a saját könyvét. ${ }^{9}$ Hasonló szempontot érvényesít Balázs Mihály, amikor a fentebb említett két antitrinitárius prédikátort illető különböző elnevezéseket vizsgálja alaposabban. ${ }^{10}$

Alszeghy Zsolt nem hitvitázó iratként interpretálja Károlyi írását, hanem tematikus alapon, Heltai Gáspár Vigasztaló könyvecskéjével együtt a reformáció és „antireformáczió” temetési énekei kapcsán. ${ }^{11}$ Mindkét munkában a vigasztalás és a tanítás együttes érvényesülését ragadja meg. Károlyi művét bibliai citátumokra épülő utasításként értékeli. Nagy Kálozi Balázs, noha leszögezi, hogy a Melius- és Károlyiéletmű egymáshoz való viszonyának értelmezésekor nem a mester és tanítvány viszony az egyetlen lehetséges irány, megállapítja, hogy Károlyit mégis Melius tevékenységéhez kapcsolják. ${ }^{12}$ Károlyi elsősorban polemizáló teológusként jelenik meg a pályaképben, emiatt lehetséges a két püspök tevékenységének szorosabb összekapcsolása. A műveket kronológiai sorrendben tárgyalja, az életrajz fordulópontjai köré szervezi azok bemutatását, rövid ismertetését. Ennek nyomán egy vegyes szempontrendszert alkalmazó, sokoldalú portréhoz jutunk.

Az Az halalrol, fel tamadasrol es az örök eletröl című elmélkedést Nagy Kálozi - Hor-

\footnotetext{
${ }^{7}$ KanYaró, Protestáns vitairatok, i. m., 329.

${ }^{8}$ Ács Pál, A szentek aluvásáról: Dévai Mátyás és a Patrona Hungariae-eszme protestáns bírálata = Religió, retorika, nemzettudat régi irodalmunkban, szerk. BITsKey István, OLÁH Szabolcs, Debrecen, Kossuth Egyetemi Kiadó, 2005, 99-112.

${ }^{9}$ Kanyaró, Protestáns vitairatok, i. m., 294.

${ }^{10}$ Balázs Mihály, Teológia és irodalom: Az Erdélyen kívüli antitrinitarizmus kezdetei, Bp., Balassi, 1998, 107-109.

${ }^{11}$ Alszeghy Zsolt, A magyar reformáczió és antireformáczió temetési énekei, ItK, 1916/1, 1-22.

${ }^{12}$ „Nem mondható Melius tanítványának, még kevésbé utánzójának. Annál rendszeresebb, higgadtabb és mindenképpen önálló egyéniség. Szorosabb munkaközösségi viszony sincsen köztük, mint aminő létrehozta a nagy bibliafordításokat, Heltaiét és Károlyiét." NAGY KÁLOZI, i. m., 475.
} 
váth Jánoshoz hasonlóan ${ }^{13}$ - Károlyi Péter legszemélyesebb alkotásának tekinti. ${ }^{14} \mathrm{Az}$ ajánlást elsősorban életrajzi vonatkozásban elemzi. Vélekedése szerint az apokalipszis eljövetelének érzete - amely általános volt a korban - lehetett a mű megírásának az egyik oka. Megemlíti azt is, hogy az írás válasz Sommer János és Tót Miklós könyvére. ${ }^{15}$ Értékelésében Nagy Kálozi Balázs ugyan figyelembe veszi a vigasztalás szándékát, azonban az elmélkedésre mint müfaji lehetőségre nem tér ki, mindössze a mű szerkezeti felépítését elemzi nagyobb terjedelemben. A legutóbbi - részletesebben argumentált - vizsgálódást Oláh Szabolcs végezte el, ${ }^{16}$ aki a "Sum ego, quod tu eris; quod tu es, ante fui” szállóige protestáns alkalmazása felől közelített a szöveghez: azokat az érveket elemezte retorikai szempontból, amelyek a halálról való gondolkodás hasznosságát támasztják alá. ${ }^{17}$

Ebből a rövid áttekintésből is látható, hogy Károlyinak ezt az írását legtöbben elsősorban kátészerű oktató írásként vagy hitvitázó iratként értékelték. A 20. század első felében uralkodó volt az a nézet, amely Melius életművének folytatásaként interpretálta Károlyi Péter írását.

A mü teljes címe Az halalrol, fel tamadasrol es az örök eletröl haznos es szükseges köniveczke az kereztienek epoeletekre es vigaztalasokra, ${ }^{18}$ amiből nyilvánvaló, hogy épülésre és vigasztalásra szánt írás következik. Amennyiben az elmélkedés müfaja felől szeretnénk közelíteni a szöveghez, rögtön szembekerülünk az elmélkedés vagy meditáció definíciójának képlékeny voltával. ${ }^{19}$ A 16 . századi protestáns elmélkedésekkel kapcsolatos magyar szakirodalom pedig mindössze néhány tételt tesz ki.

\footnotetext{
${ }^{13}$ Horváth János A reformáció jegyében címü monográfiájában (Honváth János, A reformáció jegyében: A Mohács utáni félszázad magyar irodalomszemlélete, Bp., Akadémiai, 1953, 300-301.) röviden bemutatja Károlyi Péter életművét, hangsúlyozza az irat személyességét (ez a félmondat azóta öröklődő közhely lett a Károlyi-szakirodalomban), illetve jellemzi a felépítését. Több megállapítását átveszi Nagy Kálozi Balázs munkája.

${ }^{14}$ NAgY KÁlOZI, i. m., 509-512.

${ }^{15}$ Uo., 510.

${ }^{16}$ OLÁH Szabolcs, Pesti György haláltáncénekei és a protestáns versszerzési gyakorlat: A szövegforrások eltéréseinek textológiai és alaktani-szemléleti vizsgálata, ItK, 1996/5-6, 582-612.

${ }^{17}$ Uo., 592-593. Ezt követően Pesti György a testi halálhoz kapcsolható megfogalmazása tárgyalásánál kerül ismét elő az elmélkedés, abban a tekintetben, hogy Károlyi milyen hasznokat sorol fel a halálról való megemlékezés mellett.

${ }^{18}$ KÁrolyi Péter, Az halalrol, fel tamadasrol, es az örök eletröl haznos es szükseges könyvecske, az keresztyenek epöletekre es vigasztalasokra, Debrecen, Komlós András, 1575 (RMNy 358, RMK I, 116). A Tiszántúli Református Egyházkerületi és Kollégiumi Nagykönyvtár RMK 145 jelzettel ellátott példányát használtam. ${ }^{19}$ Vö. GÁвоR Csilla, „Religiosa actio mentis”: Meditációelmélet és meditációtípusok a kora újkorban Európában és Magyarországon = Devóciók, történelmek, identitások, szerk. GáвоR Csilla, Kolozsvár, Scientia, 2004, 9-60, illetve Uö, Elmélkedés, meditáció: a kutatás állása, feladatok, tervek = Lelkiségtörténeti számvetés, szerk. Szelestei Nagy László, Piliscsaba, PPKE BTK, 2008, 55-63.
} 
A katolikus meditációval más a helyzet, ennek elemzése azonban kívül esik tanulmányom tárgyán. ${ }^{20}$ Ebben a században a protestáns elmélkedések is nagyobb teret nyertek. Az 1600-as években Károlyi Péter mellett Balassi Bálint, Heltai Gáspár és Ecsedi Báthory István ${ }^{21}$ elmélkedő prózája mondható jelentősebb tételnek a korszak protestáns egyházi irodalmában, bár mindhárom jelentős időbeli távolságra helyezkedik el a tárgyalt mütől: Heltai műve 1553-ban, Balassi Bálinté először Krakkóban jelent meg 1572-ben, ${ }^{22}$ míg Ecsedi Báthoryé az 1580-as években keletkezett, utóbbi ráadásul kéziratos formában maradt.

Uray Piroska mutatott rá a katolikus és a protestáns meditáció/elmélkedés hasonlóságaira. ${ }^{23} \mathrm{Az}$ elmélkedés müfaját Meszesán Mária szintén úgy jellemzi egy tanulmányában, hogy alapvetően a nyilvános prédikáció és a meghitt imádság kereszteződéséről van szó. ${ }^{24} \mathrm{~A} 16$. században egyre gyakoribbak lettek azok a protestáns írások, amelyek meditatio vagy contemplatio megjelöléssel láttak napvilágot. Uray arra hívja fel a figyelmet, hogy magyarul az elmélkedés kifejezés magában foglalja mind a meditatio, mind a contemplatio jelentését. A meditatio Szent Bonaventura szerint a rejtett igazságok feltalálására szolgál, míg a contemplatio a felfedett igazságok szemlélésével egyenlő. Az alapvető jellegzetességeket átvették a protestáns szerzők is, azonban nem változtatás nélkül. Heltai János a 17. századot dolgozza fel Müfajok és müvek címü monográfiájában. Az elmélkedések kapcsán az egyik jellegzetességnek nevezi azt, hogy heterogén szövegek sorolhatóak ide, és fontos tulajdonságuknak tartja, hogy elsősorban Isten és ember egymáshoz való viszonyára kérdeznek rá, és igyekeznek erre választ adni. ${ }^{25}$

A következőkben tehát arra a kérdésre keresem a választ, hogy mennyire viseli magán az elmélkedés egyes jegyeit Károlyi Péter írása.

\footnotetext{
${ }^{20} \mathrm{Az}$ utóbbi két évtizedben több tanulmány, monográfia foglalkozott a katolikus meditációval (többek között Tüskés Gábor, Knapp Éva, Gábor Csilla munkái), amelyek részletes ismertetésétől itt most eltekintek. ${ }^{21}$ Ecsedi Báthory István meditációinak vizsgálata újabban: BALÁzs Mihály, Ujjabb szempontok Ecsedy Báthory István meditációinak értelmezéséhez, illetve PÉNTEK Veronika, Devóció és magántörténelem a 16-17. század fordulójának elmélkedö irodalmában = Emlékezet és devóció a régi magyar irodalomban, szerk. BALÁzs Mihály, GÁвоR Csilla, Kolozsvár, Bolyai Társaság, Egyetemi Műhely Kiadó, 2004, 129-137, 137-149. ${ }^{22}$ Az eredeti és a későbbi kiadások viszonyához lásd legújabban Köszegry Péter, Balassi Bálint Füves kertecskéjéröl = Translatio Librorum, i. m., 75-91.

${ }^{23}$ PÉCsI Lukács, Szent Ágoston doktornak elmélkedő, magánbeszélö és naponként való imádsági, a fakszimile szövegét közzéteszi Kőszeghy Péter, kísérőtan. URAY Piroska, Bp., MTA Irodalomtudományi Intézete, 1988. Ezt támasztja alá Gábor Csilla több írásában: vö. 19. jegyzet, illetve Uő, Meditáció, teológia, nyelvalkotás: Roberto Bellarmino elmélkedő könyvének magyar fordítása = Kegyesség, kultusz, távolítás: Irodalomtudományi tanulmányok, szerk. Gábor Csilla, Selyem Zsuzsa, Kolozsvár, Scientia, 2002, 30.

${ }^{24}$ Meszesán Mária, Topológia és tropológia elhajlásai, avagy a halál és élet retorikája Madarász Márton elmélkedésében, Egyháztörténeti Szemle, 2010/2, http://www.uni-miskolc.hu/ egyhtort/cikkek/meszesan. htm. (Letöltés ideje: 2012. október 24.)

${ }^{25}$ Heltai János, Müfajok és müvek a XVII. század magyarországi könyvkiadásában (1601-1655), Bp., Universitas, 2008, 79-82.
} 
3.

A szöveg ajánlásának címzettje Bocskai Erzsébet, Báthory Kristóf bihari főispán felesége. Károlyi Péter előszava azonban nem csak az ő személyes használatára javasolja az elmélkedő iratot. Bocskai Erzsébet lehetséges példaképként aposztrofálódik: „Eloszor, hog az Nagsagod boczoletes pelda adasaval egiet kereztienek is ez koniveczkenek olvasasara fel inditassanak." ${ }^{26}$ A szerző a captatio benevolentiae részeként kiemeli munkájának hasznos voltát, viszont ennél többet szeretne teljesíteni. A szöveg ugyanis egyszersmind vigasztalást nyújt magának a szerzőnek, tanúskodik Károlyi Péter hitéről, emellett pedig másoknak ad lelki felkészülést életük végére. A közönség jóval szélesebbé válik ezen kitételek révén.

A mű létrejöttét hitelesíti az a topikus jellegű történet is, amelyet saját betegségéről oszt meg Károlyi az olvasóval. Amikor Váradon tartózkodott, súlyos beteg lett, és ráébredt, hogy szükség lenne olyan könyvekre, amelyek a halál gondolatával foglalkoznak, mivel az ember a halál előtt van kitéve a legnagyobb kísértéseknek, amelyekkel meg kell küzdeni. Megfogadta, ha meggyógyul, akkor ír egy ilyen kötetet, a szöveg a fogadalom valóra váltásának a terméke.

A halál előtt állók vigasztalása során nem elégséges a vonatkozó bibliai igék passzív befogadása. Akkor is birtokában kell lenniük ennek a tudásnak, ha vigasztalnak valakit, és akkor is, ha ők maguk szorulnak vigasztalásra. Ezzel a megjelöléssel egy aktív hitgyakorlási modellt ír le Károlyi: ezt megerősítendő Jób példáját állítja az olvasó elé. Érvelése szerint a vigasztaló-vigasztalt párosában mindkét félnek készen kell állnia a cselekvésre: nem elegendő a prédikátorok szavát hallgatni, hanem nekik maguknak kell olvasni, önállóan elmélkedni a halál közeledtével. Ezáltal válik érthetővé az a követelmény is, hogy a vigaszra szorulónak önerejéből is képesnek kell lennie arra, hogy a Biblia segítségével/ismeretével boldoguljon. Ebben a modellben előtérbe kerül a vigasztalás egyéni jellege, viszont nem zárja ki a közösségi formát sem.

$\mathrm{Az}$ ajánlás szövegében váradi prédikátorként definiálja magát a szerző, a közösség felé forduló gondviselő szerepe, az ehhez kapcsolódó felelősség határozza meg a megszólalását. A prédikátorszerep mellett továbbra is a közösség része marad. Az írás aktusa révén végrehajtott cselekvések - a bibliai helyek applikálása a halálra való felkészüléshez - őt magát is képessé teszik a halállal való szembenézésre. A szöveg egyben saját hitének is a dokumentációja: „Es noha szandekom es ugiekezetem ez hog ennek utanna az kereztieni tudomaniak minden cikkelirol rovideden iriak, mind az altal, ha az Ur Isten ezenkozben az vilagbol az eletre ki hiv, ez koniveczke az en vallasom felol tano bizonsagot teszen, melibe az Urnak lelke altal mind vegig meg akarok maradni." ${ }^{27}$

A keresztény hívők közösségéhez tartozást erősíti a nyelvi megformálás: alig követhetően változtatja az igealakok személyét, az egyes és többes szám második,

\footnotetext{
${ }^{26}$ Károlyi, Az halalrol, fel tamadasrol, i. m., $\mathrm{A}_{3}{ }^{\mathrm{a}}$.

${ }^{27}$ Uo., $\mathrm{A}_{3}^{\mathrm{b}}$.
} 
többes szám első, valamint az egyes szám első személyek keveredése folyamatosan módosítják a szöveg hangnemét. Az írás megszületésének okaként az ajánlás a hiány pótlását jelölte meg. A szerző a már ismertetett betegségtörténeten kívül levélben megfogalmazott kérésekre utal, azonban ezeknek egyelőre nem bukkantam a nyomára. Harmadik érve, hogy az emberek nem törődnek a halállal. A félelem miatt ugyanis inkább azon igyekeznek, hogy megfeledkezzenek erről az elkerülhetetlen eseményről. A felejtés oka - ahogyan azt Károlyi az első kérdésben kifejti - az emberi természet romlottsága, a földi boldogság keresése, valamint a már említett félelem. Ezért kap részletes indoklást az első kérdés válasza, amely azt bizonyítja, hogy szükséges a halálról való gondolkodás.

A felejtés ellenében az emlékezés, a memoria fontossága mellett érvel Károlyi. A halál bizonyosságára való emlékezés, a félelemmel történő ismételt szembesülés a napi elmélkedés révén a reformáció felfogása szerint hatástalanítja a haláltól való rettegést, és biztos felkészülést nyújt, mire a hívek valóban elérkeznek életük végéhez. A földi élet összefügg az Ádám révén öröklődő bűnnel. A halál tényének elfogadása magával hozza a bünösség belátását is, mivel Ádám büne miatt lett az ember sorsa elkerülhetetlenül a halál. A szembenézés révén egyfajta álomból ébrednek fel a keresztények, megerősítik saját hitüket, valamint elhatárolódnak a hitetlenektől, pogányoktól: „Hog annakokaert az halaltol Pogan modra meg ne rettennionk, ez kovetkezo dolgokkal vigaztalliuk, batoricziuk, es erossicziuk mind mi magonkat, mind az mi felebaratainkat".28

Károlyi szövegében markánsan körvonalazódik a hívők és a hitetlenek magatartásbeli elkülönülése: a hívő nem hárítja el az emlékezés, a szembesülés feladatát, ezáltal biztosítja maga számára az örök életet. A halál Károlyi számára is ajtó vagy kapu az örökkévalóság felé. A földi élet vége így mindössze egy állomás, azonban nem mindegy, hogy mihez vezet ez az átjáró. A szöveg alapján nyilvánvaló, hogy választható a hitetlen élet, azonban ennek a következményeire is felhívja Károlyi a figyelmet. A hívőkkel ellentétben ugyanis a hitetlenek a kínok közé jutnak, a nem megfelelő élet nyomán nem az örök élet lesz az eredmény, hanem a feltámadás is halállá alakul át. Ennek illusztrálása részletező módon történik, többször előkerül a Lk 16: a hitetlenek földi életük alatt vakságot mutatnak Isten felé, nem vetnek számot saját büneikkel, életükkel. A halál után az eddig megtagadott látás révén tapasztalják meg kétséget kizáróan életük hibás voltát.

A bibliai citátumok elsősorban érvek szerepét töltik be a kérdések tárgyalása során. Szerzőnk úgy fogalmaz, hogy a halál felől mondja a Szentírás summáját, amely azonban nem elegendő a vigasztalás teljes megvalósulásához. Nélkülözhetetlen a tanítások megismerése és magyarázata: a vigasztalás akkor lehetséges, ha megértjük az alapvető tanításokat a halállal kapcsolatban. Ez az érv tér vissza akkor is, amikor a pogány bölcsek írásairól szól. Tisztában van vele, hogy korábban is születtek vigasztaló írások,

\footnotetext{
${ }^{28}$ Uo., $S^{\mathrm{b}}$.
} 
azonban elveti ezek használatát, ugyanis azok nem tudták mi a halál, honnan ered, valamint hogy hogyan szabadulhatnak meg a félelemtől. A teljes megismerés, a biztos, Szentíráson nyugvó tudás az, ami elvezethet Istenhez, és ezáltal a „Szentlélek templomaivá" válhatnak a hívek.

4.

Az épülés, a hasznosság igénye már az ajánlásban kifejezésre jut, ahogyan a vigasztalás is. Azonban felmerülhet a kérdés, hogy mit is ért Károlyi vigasztaláson.

A 13. kérdésben olvasható a kilenc vigasztalás, amelyek elsősorban a már kifejtett problémákat foglalják magukba, a halál eseményének az elkerülhetetlenségétől az örök élet boldogságáig jutnak el. Útmutató jelleggel bírnak, az alapos érvelésnek köszönhetően nincs szükség további bizonyításra. Formailag tehát egyetlen kérdésre korlátozódna a vigasztalás, amelyet Károlyi az olvasónak szán. Azonban maga a szerző fogalmaz úgy az ajánlásban, hogy az írás folyamata beteljesíti a vigasztalást a bibliai szövegek keresése és olvasása révén. A szóban forgó mü erőteljesen biblikus, a Biblia pretextusa Károlyi írásának. Ezen szövegek felhasználása nem merül ki abban, hogy Károlyi érvekként, valamint saját hitének igazolására használja ezeket, támadhatatlanná téve ezzel állításait. Többször találkozunk olyan utasításokkal, amelyek a Biblia fellapozását igénylik, alapvetően együtt olvastatja szövegét az általa kijelölt locusokkal: „Ez mikeppen legien olvasd meg bovebben Roma 7.”29 Az olvasás során megismétlödik a bibliai citátumok előkeresése, ezáltal képződik meg az a vigasztalásélmény, amelyet a szerző megfogalmaz ajánlásában.

A 14-19. kérdések már a Sátán kísértéseit tárgyalják, amelyek a halált megelőző időben érhetik legerőteljesebben a távozókat. A kísértések esetében formát vált Károlyi: dialógusokban példázza azt, hogyan háríthatja el a hívő a Sátán érveit. Ezek az érvek ugyanazokat az állomásokat járják be, mint a szerző addigi fejtegetései, kiforgatva azonban Károlyi korábbi okfejtését. A vigasztalások a halál, valamint a halált követő léthez kapcsolódnak. A Sátán viszont a földi élethez fordul érvelésében: az elkövetett bünök, a földi szenvedések szolgáltatják a kísértések alapját.

Károlyi Péter kátészerű szerkezetet alkalmazott, összesen huszonnégy kérdés-feleletre osztott részből áll a mű. Az első 12 egységben a halállal kapcsolatos főbb tételeket bontja ki, amelyek tisztázzák annak mibenlétét és természetét. A szerző igyekszik lebontani a halál elfelejtését és emlékezésbe fordítani. A szöveg felépítését elsősorban a docere szándéka határozza meg, ez szabja meg a vigasztalások helyét és formáját. Jellemző a logikus okfejtés, az érvelést irányító további kérdések megfogalmazása egy-egy egységen belül. Károlyi elsődleges szándéka a meggyőzés, lévén, hogy igazolni kívánja a halál problematikájának kikerülhetetlenségét a személyes életvezetésben azok számára, akik ezt még nem tudatosították magukban.

${ }^{29} \mathrm{Uo}, \mathrm{E}_{32}{ }^{\mathrm{a}}$. 
A szakirodalomban két vitával is kapcsolatba hozzák Károlyi munkáját. Az egyik az unitáriusokkal, a másik pedig a lélekkel kapcsolatos, és mindkettőben központi szerepe lenne ennek az írásnak, noha nem mindegyik szakirodalom tárgyalja mind a két vonatkozásban. Több hitvita jellegü kérdés is beépül a szövegbe.

Ezek a teológiai problémák több kérdésben is előkerülnek, viszont ez a kisebb hányadát jelenti a szövegnek: a 4. és az 5. és 18. kérdésben rövidebb utalás történik az ellentétes véleményekre. A 7. és a 21. kérdés elemzi részletesebben az ellentéteket, és reagál az ellenvéleményekre, azonban a szöveg alapján nem feltétlenül vitaszituáció az ott olvasható érvelésrendszer. Az utóbbi két kérdés szinte önálló egység a teljes művön belül. A 7. kérdés Blandrata és Dávid Ferenc említésével kezdődik, aztán tér át a szöveg Tót Miklós és Sommer János munkájára. Ezt röviden ismerteti és rámutat tévedéseikre (elsősorban Tót Miklós álláspontjával kapcsolatban), ${ }^{30}$ azonban a kérdés végén határozottan véget vet a probléma tárgyalásának: „Az tob okoskodasokat hatra hagiom mostan, mert ezekbol konijo az tobbit meg feitenonk, es minekonk az Apostoli Credo mellol nem kel el mennonk, meliben ezt valliuk. hiszem az testnek fel tamadasat. Amen." ${ }^{31}$

A 21. kérdésben nem foglalkozik az unitárius vélekedésekkel: a kérdés a „Hova megy az ember lelke a halál után?”. A szöveg az evangélikus és református álláspontok közti ellentétet regisztrálja, azonban megfogalmazza kétségeit is a vita jelentőségével kapcsolatban:

Emlekezem rea, hog az vissza vonas nagi giulolseggel es az Szenteknek botrankozasokkal agitaltatot, forgattatot az mi meg holt attiak fiai kozot, Petrus Melius es Starai Mihali kozot. De en nem itelem, hogi ez ertelemben valo kulombseg oly nag dolog legien, hog az Attiafiui zeretetet fel bonczia, es ezert botrankozassal az Ecclesiaban nagi haborusag indittassek. En az en ertelmemet, melliet hiszek es vallok Iras szerent lenni, rovideden ez dologrol meg mondom. ${ }^{32}$

A katolikusok - egészen pontosan a pápa - többször megkapja az Antikrisztus megnevezést; az evangélikus és kálvinista felfogás közötti különbség vitanyitó ereje előtt valamennyire értetlenül áll a szerző. Nem helyezkedik vitapozícióba a lutheránus állásponttal szemben, véleménye szerint nem az az igazán fontos kérdés, hogy hova kerül a lélek, hanem hogy hogyan jut el a halálig.

\footnotetext{
${ }^{30}$ A 7. kérdés részletes elemzését lásd PIRNÁT Antal, Néhány adalék Johann Sommer és Melius Péter müveinek bibliográfiájához = Collectanea Tiburtiana: Tanulmányok Klaniczay Tibor tiszteletére, szerk. GALAVICs Géza, Herner János, Keserü Bálint, Szeged, JATE, 1990, 179-185.

${ }^{31}$ KÁrolyi, Az halalrol, fel tamadasrol, i. m., $\mathrm{M}_{3}{ }^{\mathrm{a}}$.

${ }^{32} \mathrm{Uo}, \mathrm{Z}_{3}^{\mathrm{b}}$.
} 
A hangsúly a helyes élet módozataira kerül, a feltámadás, illetve az örök élet lokalizálása az elméleti problémák közé sorolódik: ennek a vitának nincs szerepe abban, hogy milyen a mindennapi magatartásunk, és hogy megfelelöen felkészültünk-e a földi lét lezárására.

6.

$\mathrm{Az} A z$ halalrol, fel tamadasrol es az örök eletröl sikeresen illeszti egymáshoz a heterogén szövegegységeket, amelyeknek keretet ad Károlyi Péter tanúságtétele. Kérdéses a Károlyi-szöveg célközönsége. Ugyan az ajánlás Bocskai Erzsébetet említi, illetve „együgyü” keresztényeket, a szöveg elvár egy bizonyos müveltséget olvasójától: a latinul szereplö bibliai idézeteket Károlyi a legtöbb esetben lefordítja, viszont nyelvtanilag nem pontos fordítást ad, hanem az értelem visszaadására törekszik. A Biblia mellett latinul hivatkozik Ágostonra is, a 21. kérdésben hosszabb citátumot találunk a János evangélium kommentárjából fordítatlanul, bár ezt magyarázhatja a fejezet polemikusabb jellege, szakszerübb érvelésrendszere.

Noha a mü címében a halál, a feltámadás és az örök élet is szerepel, fókuszpontjában mégis a halál található. Károlyi Péter szövege mindössze a záró két kérdésben tér ki a feltámadás és az örök élet tárgyalására, azonban a nyelv nem elégséges ennek leírására. Ézsaiás és Szent Pál nyomán írja Károlyi: „az embernek szeme nem latta, file nem hallotta, szivebe meg nem gondolta". ${ }^{33} \mathrm{Az}$ örök élet boldogságát mindössze a hit garantálhatja, erre hoz bizonyítékokat zárásában. Szövege addig kíséri olvasóját, amíg az emberi értelem által is átfogható életszakaszokat elhagyja; az örökkévalóságot meg sem kísérli a nyelvi ábrázolás tárgyává tenni. Feladatát így is teljesíti: kalauzként irányítja a hívőt a földi élet lezárásához, hogy ne kelljen mástól vigasztalást remélnie.

Arra a kérdésre, hogy használták-e Károlyi írását, nem tudjuk a választ, mindöszsze Bornemiszánál olvashatunk egy megjegyzést ezzel a müvel kapcsolatban. Nincsen adatunk a példányszámról, későbbi kiadás sincs. A kortárs művek: Heltai, Balassi munkái más időpontokban láttak napvilágot, tematikájukban, szövegalkotási technikájukban jelentős eltéréseket mutatnak. Hasonló kiadvány a debreceni nyomdára sem jellemző, ezért Károlyi Péter munkája talán csak különös hírvivő arról az igényről, amely már a müfaj 17. századi felvirágzása előtt jelentkezhetett a hitviták és a prédikációskötetek között.

\footnotetext{
${ }^{33}$ Uo. $\mathrm{T}_{3}^{\mathrm{a}}$.
} 


\section{TÜNDE MóRÉ}

Meditation, Polemics and Catechism in Péter Károlyis Az Halalrol, Fel Tamadasrol es az örök eletről [On Death, Resurrection and Eternal Life]

Since Imre Bán's paper on 16th century rhetoric and poetic handbooks from 1971 only a few scholars have made further inquiries into the oeuvre of Péter Károlyi. Following a short introduction to the scholarly works of the the author, the article focuses on meditations in 16th century Hungary. The first half the paper describes Károlyi's preface written for Erzsébet Bocskai, and covers such themes as the concept of death, remembering and forgetting, while outlining the changing role of the author as a preacher in the text. The second half of the essay is devoted to examining the possible polemic contexts of this work, concentrating on the conflicts between the Reformed Church and Unitarianism in the 1570s.

The paper points out various characteristics of Károlyi's text which are combined together with great success in describing the art of good death. 